\title{
SELECTED DIMENSIONAL ASPECTS OF PERFORMANCE MUSIC EDUCATION (IN SLOVAKIA)
}

\section{Strenacikova M.}

\section{INTRODUCTION}

Education is one of the key factors in the development of every society. Already in ancient times, matters of education (initially of the younger generation, later also of teachers) became part of various philosophical tracts. Gradually, dilemmas about the education broadened, and preschoolers, adults, or seniors were added to the cogitation about child education. With the development of pedagogy as a science, the range of knowledge about education has gradually expanded, and was enriched with aspects of various non-teaching disciplines. In addition to general education, more and more attention has also been paid to professional training. Nowadays, we can find a lot of materials for example about education of athletes or children with different disabilities, but musicians' education is still not getting enough attention. Although numerous material is available in the form of methodological manuals for teaching instruments, such as organ, violin, piano, etc., more general questions about musician's education are only partially addressed. Similarly, a number of children's education publications in various fields, including music, is available, but it is dedicated to collective pupil's music education in elementary/primary school. At present, general literature on performance music education is absent in Slovakia, which motivated us to choose the topic of our article. We pay attention to selected aspects of performance music education in three dimensions: personal, organizational and philosophical.

\section{Personal dimension}

1.1. Interactive relationship teacher-pupil. In the context of changes in the society, new philosophical trends and the modern view on education, the understanding of the teacher's roles is changing. (S)he is no longer an "infallible" model for a pupil, a distant authority to obey and to listen to, 
a person providing new knowledge, giving instructions on how to play, directing the process of artistic education through directives, expecting their fulfillment and taking his/her stand on their realization (also under the threat of punishment). New humanistic education models, in which the pupil has increasingly higher input in his/her own education, got to the fore. The child is involved in planning, (s)he is responsible for his/her own self-development, (s)he chooses the pieces (s)he wants to play, and often, (s)he brings new "material" (often modern songs and film music) that the teacher himself does not know. Therefore, the teacher must update his/her own repertoire with contemporary music works, learn to play "by ear" and manage the interpretation of works that are often not-notated. (S)he becomes more or less a pupil's partner, with whom the pupil discusses his problems, seeks advice, tries to study repertoire (on lower education levels the teacher-pupil relationship remains asymmetric, since the pupil lacks highly developed musical awareness and cannot choose adequate works (s)he would be able to play himself/herself). The scientific literature lists many teacher roles varying with the degree of classroom control. For example, instructors, managers, evaluators, instigators, models, partners, monitors, facilitators are mentioned among foreign language teachers ${ }^{1}$. Koštrnová $^{2}$ describes the roles of a teacher in relation to his/her competences as a communicator, leader, informant, methodologist, axiologist, facilitator and diagnostician. Dominating humanistic concepts prefer in performance music education, the following teacher's roles:

- Facilitator of education and training - (s)he tries to achieve educational goals given by the state, (s)he knows educational standards and, according to them, (s)he selects pieces to play, while allowing pupils to express their own opinions. (S)he motivates their personal development.

- A guide to education - an orientator - (s)he gives pupils the opportunity to actively participate in co-deciding about their own education, allowing them to include in their repertoire also compositions that are not mentioned in state documents.

${ }^{1}$ Homolová, E. Učitel'ské a žiacke roly na hodine cudzieho jazyka. Banská Bystrica: Univerzita Mateja Bela, Fakulta humanitných vied. 2004. pp. 44-45.

2 Koštrnová, D. Tvorba a rozvoj pozitívnej klímy v triede. Bratislava: Metodickopedagogické centrum v Bratislave. 2014. pp. 40-44. 
- Co-participant of pedagogical meetings, an expert coordinating pupils' personality growth and acquisition of musical abilities - (s)he focuses not only on the composition studies, but also on the development of the pupil's personality, (s)he creates situations in which pupil's musical taste, aesthetic feelings and desirable personality traits are formed.

- A partner who helps the learner to saturate his/her educational and personal needs, both in learning and in personal life. (S)he supports not only the development of musical competences, but also pupil's selfknowledge, self-understanding, and the formation of a life-philosophy in which music and art have an irreplaceable position. (S)he restricts his/her own directivity, and becomes a peer partner, who listens carefully and shows understanding.

Less popular is currently the role of a model that the pupil tries to imitate. While in the past, the teacher often demonstrated the way of interpretation by playing instrument and wanted the pupil to repeat it as accurately as possible, now (s)he leaves the pupil more room for selfexpression and (s)he removes possible mistakes by appealing on pupil's critical thinking, by comparing different ways of interpretation, or by leading a pupil to discover his/her own mistakes based on "wrongly" sounding interpretation.

Besides the teacher, the most important component - the pupil, gets involved in interaction during music lessons. Joint classroom meetings provide a space for creating relationship that is not only a result of the education process, but also its necessary condition. There is no interaction among pupils in the instrument or singing individual lesson, and thus there is more room for creating the deep relationship between a teacher and the pupil. Teacher's activity levels oscillates depending on the particular situation and personality characteristics of involved subjects from autocratic approach through democratic to liberal; from official acting through parent-like to partner-friendship; from direct management to indirect independence encouragement. Pupil's responses further stimulate teacher's activity and thus provide a basis for further direction of interactions. Under their influence, various changes in the cognitive, conative, attitudinal, will-power and emotional spheres of both involved subjects occur. 
The way of interaction determines the quality of education and its outcomes. It becomes one of the key elements of shaping the future musician's personality and his relationships to music and the art as such. The pupil's relationship with the instrument teacher, which is usually built over many years, is very deeply ingrained in the pupil's soul (and often even in his/her subconscious). Pupils returns to their teachers many years after graduation.

1.2. Pupil's personality development. The primary subject of interest of a teacher is the pupil's progress. In order to describe changes that occur through the interactive educational relationship with the teacher, we apply the concept KEMSAK by M. Zelina ${ }^{3}$. We add the category of Existence and Being. We categorize desirable characteristics - the changes in child's personality into seven categories, which cannot be regarded as independent, but mutually influential, complementary and conditional:

1. Cognitive dimension: The pupil acquires new knowledge in music theory, history of music, theory and methodology of performance, etc. (these initially fragmentary knowledge provide at a higher level of study rather holistic picture of music interpretation). At the same time, under the proper guidance of the teacher, the pupil develops thinking (divergent, critical, associative and aesthetic), his/her memory improves (musical, short-term, long-term, auditory, tactile, visual...), his/her imagination and fantasy develop.

2. Emotional dimension: Higher emotions representation grows (social, aesthetic, ethical, intellectual, philosophical), socially desirable emotional development (empathy, tolerance, friendliness, authenticity) is supported. The teacher in the process of music education contributes significantly to the increase of pupil's emotional intelligence (both interpersonal and intrapersonal).

3. Social dimension - the pupil learns to build positive interpersonal relationships, in chamber music / ensemble / orchestra / choir singing class, (s)he learns to cooperate with others, respect them, integrate into the collective ... In the long-term time frame, (s)he learns to contribute to the development of the society.

\footnotetext{
${ }^{3}$ Zelina, M. Stratégie a metódy rozvoja osobnosti diet’at’a. Bratislava: IRIS. 1996. p. 23.
} 
4. Axiological dimension - the learner learns to evaluate art, to form adequate attitudes toward art, to accept the values created by other people and society (on the one hand, these values are the works of art, on the other hand, they hide values in themselves - love, good, truth...). In the process of musical education, a pupil improves his/her ability to make his/her own judgments based on the interiorization of external values, learns to evaluate art and himself/herself, accept freedom and responsibility for the consequences of decision making. During the lesson, the personal value system is being developed.

5. Motivational dimension - based on own artistic achievements, the pupil builds a healthy self-esteem, gets to know himself /herself and own reactions, develops self-awareness and self-knowledge. While practicing, (s)he tries to overcome his/her own limits, self-regulation and willpower (perseverance, dedication to goal, determination and autonomy) improve, the limit of frustration tolerance increases.

6. Creative dimension - through the instrument playing / singing, the pupil learns independently and creatively approach the problem solving, achieves creative independence, develops his creative imagination, his/her ability of self-expression, autocreativity improves, it moves from inventive ingenuity, through innovative flexibility to emergetive originality.

7. Dimension of existence and being - The pupil forms a worldphilosophy, an integrated image of the world, (s)he consolidates his/her own authenticity and autonomy, attains internal freedom, seeks his own course of life and tries to live a meaningful and active life.

An important component - music with its anthropocentric and artcentric aspects - enters the interaction in teaching music, enhancing the aforementioned effects of interaction on transforming the pupil's personality. "Musical art ... incorporates another individual into ties, thereby socializing him and providing space for animating oneself and others, therapeuticizing, helping to harmonize relationships and understand the cycle of lif",

${ }^{4}$ Michalová, E. Hudba vo svetle pedagogiky. In Hudební pedagogika a výchova minulost, prítomnost, budoucnost. Sborník referátů z konference konané v Olomouci ve dnech 21.-22. listopadu 2002. Olomouc: Univerzita Palackého v Olomouci. 2004. p. 51. 


\section{Organizational dimension}

The organization of the performance music education can be understood at two levels: as institutionalization within the school system and as an organization of the learning/teaching process in the classroom.

2.1. Institutional aspect of education. Performance music education in school (the term scholé - gr. leisure, freedom, opportunity...) is provided in institutions that are organized in an elaborate system. The current Slovak school system is adapted to correspond to European trends: it is divided into four levels: pre-school facilities (where playing musical instruments is not taught), elementary/primary schools (during a primary school pupil has the option to attend extra music classes in elementary/primary art school), high schools (the vocational training is provided at 6-year conservatory, professional music school, whose graduates continue to study at universities, or get a job of an instrument / singing teachers or as professional musicians - most often as members of orchestras and various musical ensembles), and universities (in Slovakia, three universities with a performing art focus were established). Pupils only attend compulsory music education, which, however, does not include a systematic musical instrument playing, in primary schools.

In organizing an institutionalized music performance educational process, we find many differences compared to general education. The pupils can attend basic performance musical classes at elementary/primary art schools, where they can graduate after finishing the first part of basic education in 8 years (however, the primary school lasts 9 years). Afterwards, they can continue their studies either at elementary/primary art school in the second part of their primary studies (at the same time they attend secondary education at another school). Another option is to study at conservatories (which provide higher secondary education for 4 years and then tertiary education for two more years). The students can receive the highest musical education by studying at the first (Bachelor $-\mathrm{Bc}$.), the second (Master of art - Mgr. art.), or the third (Doctor of art - ArtD.) degree. At universities they gain a qualification for teaching at a conservatories, for performing as soloists, chiefs of art ensembles and so on.

The music school may be founded by the church, state, natural person, community, organization, association, or a group of people. Education at music schools should focus not only on musical preparation, but also on 
providing opportunities and resources which enable the pupil to immerse himself/herself in exploring own essence, nature of being, roots.

2.2. Processual aspect. When understanding education as a process, it is necessary to consider its lifetime nature. The achieved level of music education corresponds to the habitual mode, and it expresses already acquired skills, knowledge, attitudes, values, forms of behavior. In the presence, each pupil grows in the actual mode, and while extending the zone of proximal development. The overall potential for further development of the pupil's abilities reflects the potential modus.

By specifying the organization of the process of teaching, we inevitably enter the process consisting of several phases, which teachers implement following a well-thought-through plan.

2.2.1. Initial diagnosis. The initial diagnosis is particularly important for pupils in performing music art schools. Already at the first contact of the teacher with the pupil, the current level of musical abilities of the pupil should be detected. The teacher can carry out the diagnosis in different ways, depending on the diagnosis aims, available time and material supplies. Most often he can apply:

- Explorative methods for obtaining information through oral statements (pupil's, his/her parents', or friends') or written answers (e.g. in interviews, questionnaires, or different types of tests).

- Observational methods for obtaining information based on observation (extrospection). If the teacher decides to observe the pupil, (s)he must not interfere with the course of the events and pupil's activities.

- Analysis of the process and products of activity, as a method based on the analysis of the pupil's musical or creative activities.

- Psychosemantic methods for identifying attitudes to music, pupil's orientation in its structure, and so on. The pupil indicates in the record sheet the place where (s)he places the given word, resp. a word corresponding to a sounding music. Placing words in the semantic space points on cognitive and emotional components of pupil's attitudes to music $^{5}$.

${ }^{5}$ Strenáčiková, M. Teoretické východiská učitel'skej praxe pre doplňujúce pedagogické štúdium učitel'ov umeleckých predmetov, II. diel - Pedagogická diagnostika. Banská Bystrica: Akadémia umení, Fakulta múzických umení. 2018. pp. 20-21. 
The examination of musical dispositions for the performance music studies focuses on:

- Hearing-perceptual abilities - hearing perception (localization of the sound in the space, recognition of musical and non-musical sounds, recognition of musical phrases, comparison of the tone pitch, identification of known melody, determination of the number of sounding tones in the chord).

- Sense of rhythm (walking or marching at a certain tempo, movement response to changing tempo, coordinating body movements with sounding music, comparing rhythmic motives, reproducing the rhythm heard by playing on the body / clapping / playing the easy-to-play instruments, finding a rhythmic error).

- Musical memory (comparing sound samples - deciding whether they are identical or different, finding differences in rhythm or melody, finding an error, singing melody to a familiar song text, finding familiar melody or motif on the piano).

- Musical imagination (recognizing familiar songs, movement response to music, interrupted song singing, adding a second voice to a melody - with more experienced pupils).

- Sense of tonality (completing the melody on the tonic, deciding if the tune is finished or unfinished, reproducing the motif in singing).

- Musical creativity (imitating models, changing rhythmic or melodic motives, creating a melody on a given text, rhythmizing given text, creating an accompaniment to given melody, movement responses to music).

- Fine motor skills (drawing, copying shapes, modeling, self-help skills, solving puzzles) ${ }^{6}$.

Special position in the diagnostics process have tests. Teachers can use performance tests to measure musical abilities (tests of hearing abilities, sense of rhythm, harmony, tonality, musical memory, imagination, etc.), knowledge tests (in history of music, theory of music, musical forms, musical instruments...), tests to evaluate the level of

${ }^{6}$ Strenáčiková, M. Teoretické východiská učitel'skej praxe pre doplňujúce pedagogické štúdium učitel'ov umeleckých predmetov, II. diel - Pedagogická diagnostika. Banská Bystrica: Akadémia umení, Fakulta múzických umení. 2018. pp. 25-26. 
musical creativity and musical skills (tests of instrumental or singing reproductive skills).

The result of the initial diagnosis should not only be a statement of the current state, but also answers to questions such as: "What kind of pupil is (s)he? Should (s)he be different? How could (s)he really be? How can I help him/her? Who are the other people I can ask for help?"”.

In the initial diagnosis, the teacher should have knowledge about what the pupil knows, what his/her strengths and weaknesses are, in what he excels, where his reserves are, what are his/her potential technical and expression problems, what are his/her personal qualities, motivational resources, attitudes, interests, will, etc. like.

2.2.2. Pupil's motivation. The initial diagnosis is followed by a motivational phase that is particularly important in the concept of contemporary music education. Many beginner pupils and their parents no longer perceive music schools as "schools", but as afternoon program that is a pleasant and meaningful way to spend the free time. They expect their children to learn to play a musical instrument during classes only, and they do not realize that the pupil must spend time practicing at home in order to acquire interpretative skills. Pupil's active participation in learning during his/her lesson is not enough to ensure a successful learning process meeting all objectives. The question of pupil's motivation is particularly sensitive, as it is necessary to invest a considerable amount of time and energy in practicing. Often, the question whether practicing should or should not be moved into a space of free, non-restricted children's activity through playing games arises. On the one hand, the teacher realizes that the methods of instruments practicing require multiple repetitions, but on the other hand, the idea of isolating children's activities into the so-called the world of children is currently overcome and considered to be one of the accepted conditions that caused the education crisis ${ }^{8}$.

2.2.3. Exposition and fixation. In the third phase of realization and regulation of the educational process, the teacher leads the pupil to reach the pre-formulated goals through various activities. The pupil performs

7 Kasáčová, B. - Cabanová, M. Pedagogická diagnostika. Teória a metódy diagnostikovania v elementárnej edukácii. Banská Bystrica: Vydavatel’stvo Univerzity Mateja Bela - Belianum, Pedagogická fakulta UMB. 2014. p. 23.

${ }^{8}$ Arendtová, H. Kríze kultury. Praha: Váhy. 1994. pp. 115-116. 
tasks, participates in active learning and his/her performance and behavioral indicators provide feedback for the teacher, on the basis of which (s)he regulates further direction of the educational process. In this crucial phase, musical abilities are improved and the cognitive, emotional, will and spiritual components of the pupil's personality are developed, and his/her opinions, attitudes, beliefs are formed. By playing instrument, the potential bad habits are eliminated, experiences of varying depth, duration and intensity are gained, and this stimulates the development of the pupil's personality. The accumulation of inner wealth and new experience lead to the inner transformations of the pupil's personality. His/her self-awareness rises, the integration of rational and intuitive occurs, the awareness of the present and future is built, which leads to the formation of the worldview, to the creation of new ideas about the world and consequently to the effort to improve not only one's own being but also the being of others.

2.2.4. Final diagnosis. The final phase of the educational process is the final diagnosis. At the same time, this phase becomes the initial phase of a new educational cycle. The assessment of achievement must respect the individuality of the pupil, his/her potential and should not be limited to comparison of pupil's current performance with pre-established standards and norms. When evaluating music performance, the teacher must focus not only on the technical-aesthetical aspect of the interpretation and the emotional input of the pupil, but (s)he should also take into account the time invested in the musical activity and pupil's predispositions, which constitute the limit-frame in which the actual performance is done.

The final diagnosis may (but need not) include assessment linked to classification (grading). It is necessary for the teacher to lead the pupil to self-assessment and to provide him/her with sufficient space for an active contribution to his/her own evaluation. This way, (s)he will help the pupil to develop his/her ability to evaluate his/her own performance, to critically approach his/her own interpretation skills and subsequently, to set new adequate goals leading to formulating realistic aspirations and to building self-conception and adequate self-awareness. The evaluation will be reflected in the pupil's self-esteem and self-awareness and his/her other achievements in the context of self-confirming prediction (Pygmalion and Golem effect). 
While grading (classification), the teacher must accept the possibility that the grade could be altered as the conditions are changed. The pupil is a changing element, and therefore, the teacher must take into account that even an excellent, talented pupil can perform poorly and vice versa, a pupil who has failed to demonstrate the necessary talent can improve. Assessing the pupil's artistic performance may result in grading (classification) that is consistent with the legislation. Precisely defined grading criteria are formulated in the Methodical Guideline no. 21/2009-R for the Classification and Evaluation of Elementary Art Schools Pupils and in two Edicts: Edict no. 324/2008 Coll. about Elementary/primary art school and Edict no. 245/2011 Coll., amending and supplementing the Edict of the Ministry of Education of the Slovak Republic no. 324/2008 Coll. About Elementary/primary art school.

“(1) ... (classification) Has an informative, corrective and motivational function. In the process of evaluation, the teacher applies appropriate difficulty, pedagogical tact with the pupil, respects the rights of the child and treats the pupil in humanely manners.

(2) The pupil has the right

(a) to know what will be evaluated and how;

(b) to know the outcome of each evaluation;

(c) for objective evaluation.

(3) ...Pupil's knowledge, skills and habits, which the pupil has acquired, their application in particular activities, the pupil's diligence and personal growth are graded.

(4) Pupil grading is carried out continuously ... and in the form of a summary classification",9.

Pupil's achievements can be assessed by the following grades:

“a) 1. grade-excellent,

b) 2. grade-praiseworthy,

c) 3. grade- satisfactory,

d) 4. grade-insufficient ${ }^{\text {,10 }}$.

${ }^{9}$ Metodický pokyn č. 21/2009-R na klasifikáciu a hodnotenie žiakov základných umeleckých škôl. 2009. URL: https://www.minedu.sk/metodicky-pokyn-c-212009-r-z-22decembra-2009-na-klasifikaciu-a-hodnotenie-ziakov-zakladnych-umeleckych-skol/

${ }^{10}$ Vyhláška Ministerstva školstva Slovenskej republiky č. 324/2008 Z. z. o základnej umeleckej škole URL: https://www.slov-lex.sk/pravne-predpisy/SK/ZZ/2008/324/20110901 
The pupils classification and evaluation at conservatories is also following precise guidelines. The most important document is the Methodical Guideline no. 21/2011 on the evaluation and classification of secondary school pupils, which states, for example, that "In classification ... is graded:

a) the quality of artistic expression,

b) individuality in the portrayal of the artwork,

c) the quality and range of skills (techniques) to create a work of art in accordance with the requirements of the curriculum and educational standards,

d) applying the patterns of artistic expression (stylishness),

e) ability to creatively apply acquired knowledge, experience and activities,

f) development of artistic abilities and talent,

g) regularity and systematisms in complex artistic education",11.

The pupil's achievements can be graded by grades 1 through 5, where 1 is the best performance.

\section{Philosophical dimension}

3.1. Teleological aspect. Performance music education is not a random procedure, but purposeful process that is directed towards certain goals. Their awareness enables the teacher to choose appropriate methods, means and forms of education during instrument or singing lesson.

Education coalesces teaching and rising that cannot be artificially separated from each other, but when formulating goals, it is necessary to distinguish between these two qualitatively different areas. Educational goals in performance music education can be attributed to the form of standards, norms, requirements, or competences that a pupil should at some stage meet, achieve in the learning of the curriculum. They express what kinds of skills pupils are supposed to master and to what level, what techniques of playing/singing they have to learn, what works they should interpret, what knowledge they should acquire. If we look at the process of education as a process that provides space and opportunities for discovery,

${ }^{11}$ Metodický pokyn č. 21/2011 na hodnotenie a klasifikáciu žiakov stredných škôl. Bratislava: Ministerstvo školstva, vedy výskumu a športu, Gestorský útvar: sekcia regionálneho školstva. 2011. URL: https://www.minedu.sk/data/att/461.rtf 
promotes the autonomy and authenticity of each pupil, leads it to internal integration, self-knowledge, shaping the worldview, and so on, more global "aims" of rising a child have to be formulated, but they cannot state precise evaluation standards and norms because of their problematic measurability and quantitative expression. When accepting the plurality of views on education, the uniqueness of each pupil and the peculiarities of socio-economic conditions in each family, it is advisable to formulate goals that lead to super-individual ideal that the society approves at that time. The super-individual ideal expresses the most general goals set by the state which are specified in the documents of its educational policy. Their fulfillment is at center of attention of every school, including performance music education institutions.

So far, the last, by the government approved educational program in Slovakia has been the National Programme on Education and Training in the Slovak Republic for the next 15-20 years, Millennium (in December 2002). A new National program for the development of education, Learning Slovakia, is currently being prepared. In accordance with new trends, "the ideal of education should be a good (honest, moral, highprincipled), wise (educated, creative), active (independent, hardworking, initiative) and happy (balanced, healthy) man", "The result of education should be a person prepared for lifelong learning and education, ready to adapt to a number of different changes in society in the future, a person ready to effectively carry out all his/her life roles, a person who will shape a creative lifestyle through inner motivation, emotional richness, advanced intellectual abilities, good socialization and value orientation ",13.

General objectives of education and training in the Slovak Republic are stipulated by the Act 245/2008 Coll. in $\S 4$. We choose the ones that are relevant also to music education:

"The aim of education and training is to enable the child or pupil to:

a) receive education under this Act,

12 Pasternáková, L. Nové trendy pri zefektívňovaní výučby. In Edukácia človeka problémy a výzvy pre 21. storočie. Zborník príspevkov z medzinárodnej vedeckej konferencie konanej dňa 11.12.2012 v Prešove. Prešov: Prešovská univerzita v Prešove, Fakulta humanitných a prírodných vied. Ed. Marek Lukáč. 2013. p. 413.

13 Kováčiková, D. - Sámelová, S. Filozofické, sociálne a pedagogické základy edukácie. Banská Bystrica: UMB, Belianum. 2016. p. 92. 
b) acquire competencies, especially in the area of communication skills, oral competences and written competences ... competences for lifelong learning, social competences ... cultural competences,

d) learn to correctly identify and analyze problems and to propose solutions to them, and to be able to solve them,

e) develop manual skills, creative, artistic psychomotor abilities, upto-date knowledge and to work with them on practical exercises in areas related to follow-up education or to current demands on the labor market,

f) foster respect for parents and others, for cultural and national values and traditions of the state of which (s)he is the citizen ... and for his/her own culture,

g) gain and strengthen respect for human rights and fundamental freedoms and principles set out in the Convention for the Protection of Human Rights and Fundamental Freedoms, as well as respect for the laws, and in particular the attitude towards the prevention and preventing the emergence and spread of crime and other anti-social activities,

h) prepare for a responsible life in a free society, in a spirit of understanding and tolerance, equality between a man and a woman, friendship between nations, national and ethnic groups, and religious tolerance,

i) learn to develop and cultivate his/her own personality and to educate himself/herself in the lifetime, to work in a group and to take responsibility,

j) learn to control and regulate own behavior, take care and protect own health ... and the environment and respect human ethical values... ",

National goals are the starting point for setting lower goals. The goal hierarchy is followed: national goals - general goals / ideal of education and training, school goals, goals of the subject, goals in individual grades, goals of the thematic unit, lesson, and a part of the lesson ${ }^{15}$.

Music schools pursue partial goals formulated by the state. They apply to every school (conservatories have different objectives than gymnasiums, elementary music schools have objectives other than general education

${ }^{14}$ Zákon 245/2008 o výchove a vzdelávaní (školský zákon) a o zmene a doplnení niektorých zákonov. URL: http://www.uips.sk/sub/uips.sk/images/PKvs/z245_2008.pdf

${ }_{15}$ Turek, I. Didaktika. Tretie prepracované a doplnené vydanie. Bratislava: Wolters Kluwer. 2014. p. 37. 
schools). Partial goals include goals in various study fields (singing goals differ from violin goals). The goals of music schools in Slovakia are created according to the State Education Program. According to this document, each school creates own School Education Program that respects its needs and focus.

The goals at art schools in Slovakia:

1. Elementary/primary school: "Pupils communicate and express their thoughts through expressive means of art, create artifacts and realize ideas in their own (authentic) way, consciously aesthetically perceive, orient themselves in the culture and the world of art, develop creative thinking, develop emotional intelligence, process information in art and culture, cultivate a sense of good and beauty" ${ }^{\text {, }}$.

In the music department, pupils: "are able to interpret and create a work of art at an appropriate level, orient themselves in the art types and are able to accept art, apply the acquired competencies in particular study fields in praxis, demonstrate the ability to communicate in the artistic field, acquire and correctly process information in the field of artistic instrumental interpretation, and in the field of interdisciplinary relations, analyze and creatively solve problems in the educational process $", 17$.

2. Conservatories: "The main objectives of the Conservatory education are developed abilities of a graduate, knowledge and values so that: the graduate is prepared for professional artistic and pedagogicalartistic work, acquired the ability for lifelong learning and for his personal and social development", " "The objectives of higher vocational education at the Conservatory can be grouped into four categories:

1)Personal: maximizing the potential of each pupil for personal maturation to an original, independent and creative personality of a professional artist and art teacher;

16 Štátny vzdelávací program pre základné umelecké školy. Bratislava: Štátny pedagogický ústav. 2015. p. 14. URL: http://www.statpedu.sk/files/articles/dokumenty/ino vovany-statny-vzdelavaci-program/--t--tny-vzdel--vac---program-z--kladn---umeleck----koly.pdf

17 Štátny vzdelávací program pre základné umelecké školy. Bratislava: Śtátny pedagogický ústav. 2015. p. 21. URL: http://www.statpedu.sk/files/articles/dokumenty/ino vovany-statny-vzdelavaci-program/--t--tny-vzdel--vac---program-z--kladn---umeleck----koly.pdf

18 Štátny vzdelávací program Konzervatória v SR ISCED 5 B - Vyššie odborné vzdelávanie / v zmysle $\S 16$ ods. 5 návrhu písm. b) školského zákona / A diel Konzervatórium. Bratislava: Štátny pedagogický ústav. 2008. p. 6. URL: www9.siov.sk/ ext_dok-statny-vzdelavaci-program-konzervatoria-v-sr/28919c 
2) Social: developing pupil's sense of social intercommunity, care and justice, strengthening interest in preserving national heritage and accepting cultural differences;

3)professional-orientation: developing abilities to make an informed choice of own professional use;

4)Professional artistic and artistic-pedagogical: developing artistic practical and creative skills and acquiring professional pedagogical competences $", 19$.

At the lower level, specific objectives, determined by performance and content standards, are formulated. These are:

- Subject (class) objectives - each subject focuses on specific aims; for example, the Appendix 7 of the State Educational Program for Conservatories in Slovak Republic ${ }^{20}$ states the subject aim in Physiology and Hygiene of Playing Apparatus this way: "The aim of the subject is to teach the pupil to play the instrument so that his play is based on the natural individual dispositions and does not cause health problems even due to regular, long-term stress of the psychic and playing apparatus, and thus to achieve a higher level of technical and artistic development".

- Thematic unit, lesson, lesson phases objectives - formulated by the teacher, state exact goal expressing what a learner is supposed to achieve (what knowledge to acquire, what skills to adopt, and so on). Example: The pupil can use the entire length of the string according to the duration of the notes.

In the personal level, the objective could be the pupil as a full-fledged person that Kučerová (1990) characterizes as a person, who "is authentic, creative, free, responsible, total (versatile) and holistic (harmonious) ",21. The pupil should be led to learn to live his own life, to develop his essential inner forces in accordance with the ideals of the society.

19 Štátny vzdelávací program Konzervatória v SR ISCED 5 B - Vyššie odborné vzdelávanie / v zmysle $\S 16$ ods. 5 návrhu písm. b) školského zákona / A diel Konzervatórium. Bratislava: Štátny pedagogický ústav. 2008. p. 7. URL: www9.siov.sk/ ext_dok-statny-vzdelavaci-program-konzervatoria-v-sr/28919c

20 Štátny vzdelávací program Konzervatória V SR ISCED 5 B - Vyššie odborné vzdelávanie / v zmysle § 16 ods. 5 návrhu písm. b) školského zákona / A diel Konzervatórium. Bratislava: Štátny pedagogický ústav. 2008. p. 270. URL: www9.siov.sk/ ext_dok-statny-vzdelavaci-program-konzervatoria-v-sr/28919c

${ }^{21}$ Kosová, B. Filozofické a globálne súvislosti edukácie. Banská Bystrica: Univerzita Mateja Bela, Pedagogická fakulta. 2013. p. 82. 
Well set goals stimulate and motivate the pupil, regulate his/her activities, direct his/her further development. In formulating individual educational goals, the music performance teacher can draw on the recommendations by Z. Sláviková ${ }^{22}$. Take into account the current conditions of the pupil's development - his/her developmental stage and its specifics, level of previously acquired skills, previous experience with music art, current state of mind, mood...

- Lead the learner to understand his/her essence by integrating knowledge - linking the performance with music theory, history of music, musical aesthetics, philosophy...

- Cognitively and emotionally influence the pupil - dedicate time to both, knowledge and the emotional aspects of music and the level of artistic interpretation, for example by choosing specific works, discussing the content of the work, the author's intentions and the like.

- Empower the idea of freedom by responsibility for one's own decisions and thus develop the ability to respond to the inconsistency of reality - give the pupil the opportunity to make his own decision, to choose his/her own method of interpretation and then to be responsible for his/her decisions.

- Create conditions for the development of authenticity and selfrealization - select works that are recommended by the curriculum, and also, entitle the pupil to choose works and their own way of interpretation.

- Focus on personality integration - create conditions for the pupil to grow, for the process of maturing on the path to personality integrity, support the formation of a realistic self-image (first based on outer evaluation by others, later on self-assessment), emphasize the importance of self-acceptance, with own strengths and weaknesses, and support the effort to eliminate those that are removable (for example after fa failure or making errors at concerts, competitions, etc.).

- Develop social attitudes and consolidate moral principles - appeal to appropriate social attitudes by choosing specific works and by discussing their content; concentrate on deepening the pupil's moral feelings especially during competitions and concerts, emphasize the necessity of respecting moral standards and principles.

${ }^{22}$ Sláviková, Z. Učitel' hudby na prahu 21. storočia. Prešov: Matúš. 2000. pp. 25-27. 
- Lead the pupil to his/her own intentional formation - select works that will allow the pupil to get to know himself/herself and support the desire for further development. At the same time equip the pupil with such abilities that will enable him/her to do so (reading the notation, playing by ear, perceptual self-control, etc.).

- Enhance aspirations by understanding own path - help the learner to understand his own strengths and limits, enabling him/her to set realistic goals and aspirations (help the pupil understand the importance of talent in a professional career).

In line with the political and social situation in Europe, it is important to respect the European dimension of education while formulating the educational goals and objectives and to the focus on "the process of cultivating a relationship with Europe and revealing its values",23. The teacher should also reinforce the European citizenship awareness, provide facts and build knowledge about European history, culture, art and science, hence, take advantage of the potential of works of European composers and present them not only as a subject of musical activity, but also as a source for the development of the abovementioned competences.

3.2. Axiological aspect. Performance music education creates a rich space to internalize the values that aer preferred in the society. The teacher must keep in mind that the value kernel is relational, and that the pupil himself/herself determines the value of each individual object, decides what is worthy (has a meaningful value for him/her) and what does not. The decisive factor is the pupil's experience, not the value itself. In educating a pupil, it must be clear to the teacher what is the desired value, what is to be recognized, acknowledged and accepted by him/her. In addition to generally valid value ideals (freedom, truth, democracy, tolerance, humanism, etc.), the pupil should also acquire artistic values and values related to himself/herself (for example, the value of self, selfregulatory values, etc.). It is the teacher's mission to support the pupil to such an extent that the acquired values become anchored and later, an integral part of his/her personality structure. Internalization of values is

${ }^{23}$ Manniová, J. Európska dimenzia vo výchove a vzdelávaní. In Pedagogická orientace 2004, № 1, p. 16. URL: https://journals.muni.cz/pedor/article/viewFile/7940/7200 
consistent with the taxonomy of affective functions described by D. B. Kratwohl (1969).

He describes five processes that govern the acquisition of values: acceptance/perception (value awareness, its active perception, differentiation from other values), response (change of passive perception of the value to active attention, willingness to react to the value, satisfaction from activity), valuation of values (dispose of a positive attitude toward the value, acceptance of the value, its preference), organization/integration of the value (value processing through thinking, abstraction, integration of the value into a system), integration of the value into personality character structure (integration of the value into the system of values, coherence of thought, speech and behavior, shaping the lifephilosophy, system of values, worldview $)^{24}$. A succinct graphical display of the Taxonomy of Educational Objectives - Affective Domain that can be beneficial to performance music education teachers while focusing on pupil's value profile was created by Simon Paul Atkinson (2012, 2015).

Picture 1: S. P. Atkinson: Taxonomy of Educational Objectives, Affective domain, 2015. URL: https://sijen.com/research-interests/ taxonomies/affective-domain/. Reprinted with permission of S. P. Atkinson

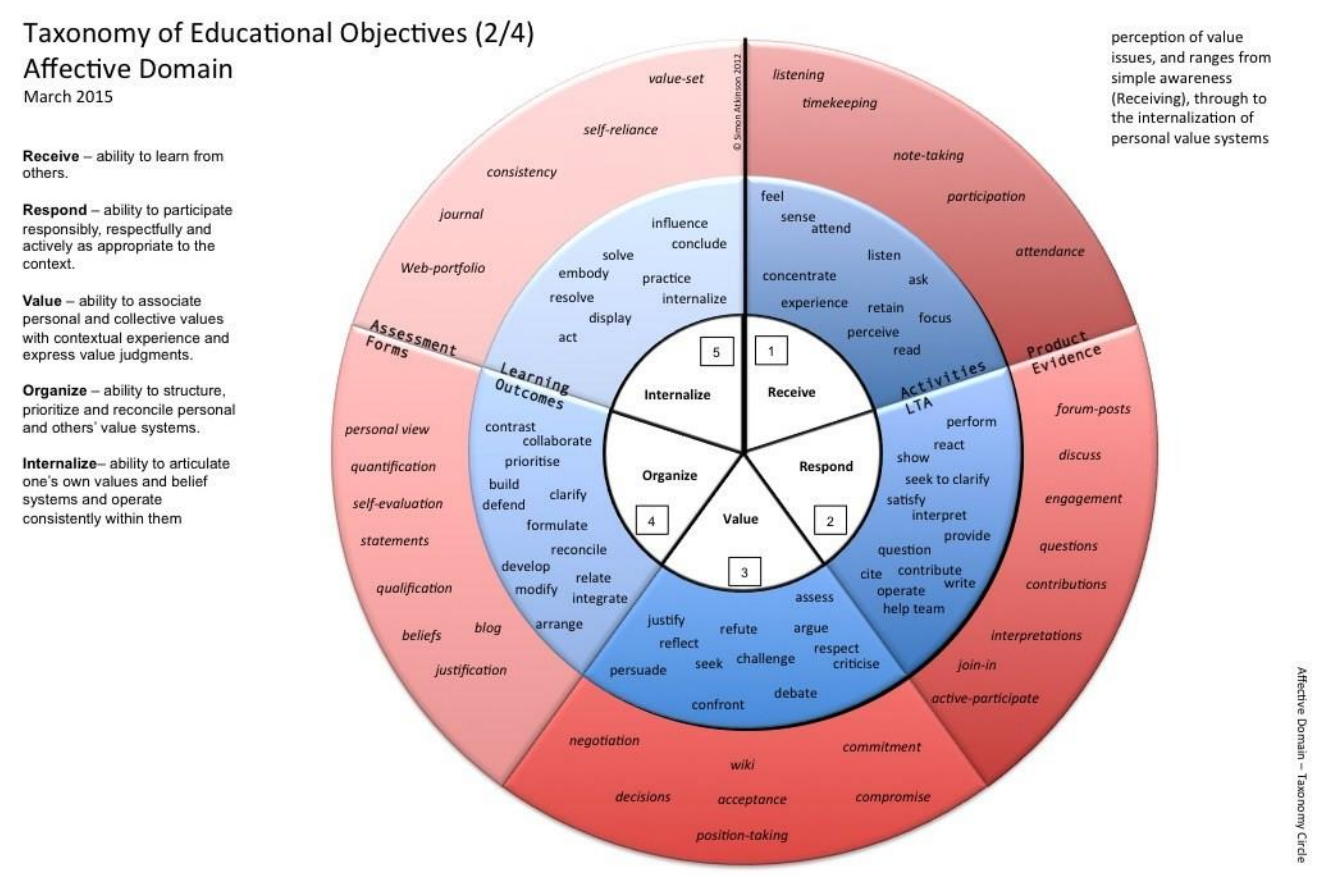

Atkinson 2012 based on the 'Taxonomy of Educational Objectives: Volume 2, The Affective Domain' (Bloom, Masia, Krathwohl) 1964.

${ }^{24}$ Turek, I. Didaktika. Tretie prepracované a doplnené vydanie. Bratislava: Wolters Kluwer. 2014. pp. 56-57. 
In praxis, if a performance music teacher wants to lead a pupil to accept and acknowledge a certain value, (s)he must "enable him/her to find a personal sense in it, by creating the conditions, so that (s)he can emotionally experience the value, gain positive experience, make decisions, be appreciated for the value, or to benefit from it, and to realize and reflect on these benefits ${ }^{, 25}$.

Art schools provide the opportunity to enter the world of "truth" (in literal translation it is an emptiness symbolizing liberation from the shadows covering true life, an opening for the arrival of what the shadows concealed, as opposed to ascholia - capture of shadows). The shadow is understood in philosophy as the face of a person which is unchangeable and the only real, but its renewal and change of expression, which are manifestations of life, are neglected. The face hides the real life of the individual. The primary purpose of education is to uncover the just mentioned faces - shadows $^{26}$.

In music education, the teacher must not forget that art is a value that pupils should acquire, and through which they should develop other (not only ethical and aesthetical) values, refine their personality and develop aesthetic relationships with themselves and their surroundings. Works of art which a pupil encounters at the instrument/singing lesson are both a means of education and a source of saturation of his/her needs and aesthetic experience. They have the potential to cultivate one's personality, including building a value system. The pressure of the society development leads teachers to present not only the beautiful and positive values hidden in music art (for example, harmony, balance, happiness and joy), but also expose them to works that portray negative phenomena in society and in human life and which evoke the experiences that are uncomfortable. The teacher must carefully select works intended for performance and lead the pupil to understand artistic legacy and to discover various aesthetic values, to search for truth, goodness and moral values in music art. The pupil should learn to appreciate and experience the desirable values during his/her meetings with music, and (s)he should acquire sufficient

${ }^{25}$ Kosová, B. Filozofické a globálne súvislosti edukácie. Banská Bystrica: Univerzita Mateja Bela, Pedagogická fakulta. 2013. p. 67.

${ }^{26}$ Palouš, R. K filosofii výchovy (Východiska fundamentální agogiky). Praha: Státní pedagogické nakladatelství. 1991. pp. 79-82. 
competences to be able to disseminate them through his/her performance and thus make the best of the potential of the spiritual power of music for the benefit of the society.

\section{CONCLUSIONS}

Performance music education is a complex phenomenon that has multiple dimensions and many aspects. Among important dimensions we recognize the personal, organizational and philosophical one. Only their thorough exploration and understanding can help create a comprehensive theory that will provide an adequate basis for the practical realization of this type of education.

\section{SUMMARY}

In Slovakia, performance music education is offered only by primary/elementary art schools, secondary music schools (conservatories) and universities with a focus on music performance. However, all of these schools are non-compulsory, optional to attend. Their mission is to prepare musicians - performers, some of whom will, in the future, ensure the growth of musical culture in an authentic environment (at various level). The learners' preparation includes not only acquisition of crucial music knowledge and skills, but also development of numerous competences, attitudes, and personality traits, i.e. characteristics that will allow them to become successful musicians in today's art world. This is possible only in a correspondence with a well thought-out complex professional approach, which on a theoretical level takes into account many aspects of education in its different dimensions. Among them, important role play: the personal dimension reflecting the desirable "changes" in the pupil's personality and the specifics of the relationship between the pupil and the teacher, the organizational dimension seeking not only a suitable organization of performance music education, but also identifying conditions and the ideal course of the performance music education process; and the philosophical dimension formulating adequate educational goals, while reflecting the requirements of current praxis.

\section{REFERENCES}

1. Arendtová, H. Kríze kultury. Praha: Váhy. 1994. 148 p. 
2. Atkinson, S. P. Taxonomy of Educational Objectives. Vol. 2: The Affective Domain. 2012, 2015. URL: https://sijen.com/research-interests/ taxonomies/affective-domain/

3. Homolová, E. Učitel'ské a žiacke roly na hodine cudzieho jazyka. Banská Bystrica: Univerzita Mateja Bela, Fakulta humanitných vied. 2004. $152 \mathrm{p}$.

4. Kasáčová, B. - Cabanová, M. Pedagogická diagnostika. Teória a metódy diagnostikovania $\mathrm{v}$ elementárnej edukácii. Banská Bystrica: Vydavatel'stvo Univerzity Mateja Bela - Belianum, Pedagogická fakulta UMB. 2014. 136 p.

5. Kosová, B. Filozofické a globálne súvislosti edukácie. Banská Bystrica: Univerzita Mateja Bela, Pedagogická fakulta. 2013. 173 p.

6. Koštrnová, D. Tvorba a rozvoj pozitívnej klímy v triede. Bratislava: Metodicko-pedagogické centrum v Bratislave. 2014. 66 p.

7. Kováčiková, D. - Sámelová, S. Filozofické, sociálne a pedagogické základy edukácie. Banská Bystrica: UMB, Belianum. 2016. 158 p.

8. Manniová, J. Európska dimenzia vo výchove a vzdelávaní. In Pedagogická orientace 2004, № 1, pp. 16-21. URL: https://journals.muni.cz/ pedor/article/viewFile/7940/7200

9. Michalová, E. Hudba vo svetle pedagogiky. In Hudebni pedagogika a výchova - minulost, prítomnost, budoucnost. Sborník referátů z konference konané v Olomouci ve dnech 21.-22. listopadu 2002. Olomouc: Univerzita Palackého v Olomouci. 2004. pp. 46-51.

10. Palouš, R. K filosofii výchovy (Východiska fundamentální agogiky). Praha: Státní pedagogické nakladatelství. 1991. 119 p.

11. Pasternáková, L. Nové trendy pri zefektívňovaní výučby. In Edukácia človeka - problémy a výzvy pre 21. storočie. Zborník príspevkov z medzinárodnej vedeckej konferencie konanej dňa 11.12.2012 v Prešove. Prešov: Prešovská univerzita v Prešove, Fakulta humanitných a prírodných vied. Ed. Marek Lukáč. 2013. pp. 413-416.

12. Sláviková, Z. Učitel' hudby na prahu 21. storočia. Prešov: Matúš. 2000. 134 p.

13. Strenáčiková, M. Teoretické východiská učitel'skej praxe pre doplňujúce pedagogické štúdium učitel'ov umeleckých predmetov, II. Diel - Pedagogická diagnostika. Banská Bystrica: Akadémia umení, Fakulta múzických umení. 2018. 90 p. 
14. Turek, I. Didaktika. Tretie prepracované a doplnené vydanie. Bratislava: Wolters Kluwer. 2014. 620 p.

15. Zelina, M. Stratégie a metódy rozvoja osobnosti diet'at'a. Bratislava: IRIS. 1996. 230 p.

\section{Information about the author:}

Strenáčiková Mária

Ph.D., Teacher of Music Arts, Academy of Arts

4002/20, Jána Kollára str., Banská Bystrica, 97401, Slovakia 